\title{
Recognition of knowledge and skills at work: In whose interests?
}

Leif Berglund and Per Andersson

\section{Linköping University Post Print}

N.B.: When citing this work, cite the original article.

Original Publication:

Leif Berglund and Per Andersson, Recognition of knowledge and skills at work: In whose interests?, 2012, Journal of Workplace Learning, (24), 2, 73-84.

http://dx.doi.org/10.1108/13665621211201670

Copyright: Emerald

http://www.emeraldinsight.com/

Postprint available at: Linköping University Electronic Press

http://urn.kb.se/resolve?urn=urn:nbn:se:liu:diva-75843 


\title{
Recognition of knowledge and skills at work: in whose interests?
}

\author{
Leif Berglund, Per Andersson
}

\section{Introduction}

The Recognition of Prior Learning (RPL) is gaining ground as a method for the assessment and evaluation of a person's knowledge and skills (Challis, 1993; VEETAC, 1993; Evans, 2003; Andersson and Harris, 2006; Andersson and Fejes, 2010). In general terms, RPL means that knowledge and skills, often achieved and developed in the workplace, can be documented and evaluated through a more or less structured process. The outcomes can be shortened educational paths and/or progression in employment. In Sweden most of the stakeholders in the field of RPL embrace the following definition:

Validation is 'a process of a structured assessment, valuing, documentation and recognition of
knowledge and competences that an individual has gained, irrespective of how they have been
acquired'. (Ministry of Education, 2003, p. 19 [English translation from The Swedish National
Agency for Higher Vocational Education])

Thus, the term used in Sweden is Validation. RPL, or Validation, has mostly been used within the Adult Education field, by the Swedish Public Employment Service and related bodies and also by municipalities interested in raising the educational levels of particular employee groups such as care workers with the elderly and with children.

Since its entry into European policy debates, the main issue and challenge for RPL has been the precise role it can play and the extent to which it can address the twin goals of increasing educational levels and employment rates among European citizens (Colardyn, 1997;

Bjørnåvold, 2000; Colardyn and Bjørnåvold, 2004; Kok, 2004). The main idea in this regard seems to be that RPL is being used among unemployed people to either direct their career paths, shorten time spent in education or ease transition to new employment. In all cases, the strength of RPL is that unaccredited knowledge and skills can be brought into the open for everyone to see and, in a sense, come into use. And here the challenge seems to lie.

Knowledge and skills developed in the workplace are seldom documented or officially acknowledged. Although RPL is quite well known among Swedish industries, municipalities, companies and other employers, it remains under-used as a way to articulate the knowledge and skills of employees (Berglund, 2010). The reasons for employers' reluctance to make use of RPL for the official assessment of workplace knowledge and skills are of course many and familiar. The risk of investing in education and assessment is that you can lose it when/if employees leave the organisation after their skills have been made visible. Recognition and assessment throw light onto competence that may not have been highlighted before, something that can become a reason for union and employee demands for financial compensation. On the other hand, visible and officially documented knowledge and skills, whether via formal education or RPL, can be important cornerstones not only in terms of meeting production demands but also by enhancing the legitimacy of the organisation (Weber, 1978; Beetham, 1991; Nordhaug, 1993). This can be seen as presenting two unsolvable dilemmas - for employers who want competence to be visible and controlled and for employees who develop valuable knowledge and skills which without acknowledgement remains contextually trapped within the organisation. 
This article aims to exemplify and analyse the employers' rationales and logics in assessing the knowledge and skills that the organisations use, and want to use, in production and related activities. Examples from four different Swedish organisations, two companies and two divisions of two different municipalities are used to compare these logics with traditional RPL activities in order to demonstrate their different social purposes. The main point that we want to stress is that it is crucial to understand this employer logic if and when trying to establish RPL within the workplace.

\section{The need for the recognition of informally developed skills}

The reintroduction of the concept of lifelong learning into education policy in the mid-1990s emphasised the economy and the demands of the labour market for increased participation and better-educated employees, rather than the social aspects of learning (Rubenson, 1996). In the Lisbon strategy and documentation thereafter, the relation between education and the development of competence was stressed (Kok, 2004). The introduction of RPL can to a large extent be interpreted as a contribution to fulfilling this objective. The underlying assumptions in lifelong learning and in RPL are that non-formal and informal learning can and should be evaluated in order to acquire the same status as formal learning (Romaniuk and Snart, 2000). However, this endeavour presents huge challenges because non-formal and informal learning have by definition been viewed as a lower status negative pole of formal learning (Bjørnåvold, 2000). Furthermore, informal learning can be unarticulated and tacit. Regardless of this, RPL has been used for a relatively long period of time to transform non-formal and informal learning into more or less formal learning, in the form of officially acknowledged certificates (Andersson et al., 2004).

The purpose of RPL has been the subject of longstanding debate. In formative approaches the purpose is to use RPL as an aid to adjusting, informing and leading the learning process, whereas summative approaches are more focused on cumulating the content and the value of the knowledge and skills that are being assessed (Bjørnåvold, 2000; Andersson and Harris, 2006; Andersson and Fejes, 2010). This division should not be overly polarised, but rather be seen as two generalised ways to meet the needs of a person whose skills are being assessed. The formative approach has perhaps a clearer focus on the learning process, whereas the summative approach emphasises the results or outcomes of learning.

In Sweden there has been a particularly strong emphasis on RPL as a way to obtain upper secondary school certificates (Lundgren, 2005; Tursell, 2005). As such, the objective of RPL can to a large extent be seen as summative i.e. a way to transform non-formal and informal learning into formal learning, as defined by officially approved certificates. However, in this article, a formative perspective is pertinent because the concern is about making workplace non-formal and informal learning more visible and recognisable. That learning may not actually leave the workplace within which it was developed and it may not need to be formally documented in any summative way.

Workplace learning and competence have been well debated in the literature (Ellström, 1992; Nordhaug, 1993; Lave and Wenger, 1991; Fenwick, 2005; Fenwick, 2006; Billet, 2006). Many theorists now question the conception of the individual as the sole owner of the knowledge and skills assessed in RPL, in favour of highlighting the relationship between the individual and the collective, between competence and context and between the objective and subjective aspects of competence (Billet et al., 2006). This implies that workplace competence is not easily understood, let alone assessed. 
Since RPL has frequently targeted unemployed people who often also require educational enhancement, the issue of using RPL in the workplace is a relatively recent one in Sweden. In this regard, Nordhaug (1993) demonstrates how the development of competence in the workplace follows a descending scale the lower the educational level. This means that the higher up in the organisational hierarchy a person is positioned, the greater share of the competence development he/she will get. A possible solution to reduce this unequal diffusion of competence development within the organisation is discussed by Romaniuk and Snart (2000) in terms of the importance of moving from employment to employability. They propose the introduction of portfolios where employees can in different ways take responsibility for the documentation of the competences they achieve at work. This may highlight areas where the work situation needs greater flexibility and where there is a readiness for change. In a similar vein, Boud (2000) also highlights the importance of looking at learning as a lifelong project, where individuals need to learn to identify and in a sense verify their own learning achievements throughout life, including in the workplace.

In Sweden, one of the areas where RPL has actually been used in the workplace is in the context of in-service training for care workers, particularly in elderly care. Here, the intention is to use RPL to document existing competence and also to act in a formative capacity in relation to further training leading in turn to summative, formal qualifications (see e.g. Fejes and Andersson, 2009; Sandberg, 2010). However, one of the risks of paying too much attention to the summative aspects of assessment is that formal learning is privileged at the expense of non-formal and informal learning at work, to the detriment of individuals, companies and society. Research and practice in this area show that RPL can make an important contribution to both the companies' need for competence and the individual's need for employability (Challis, 1993; Evans 2003; Andersson et al., 2004).

\section{Research methods}

Data from four organisations has been used for this article. All of the organisations are located on the coastline of the Gulf of Bothnia in the north of Sweden. Rönnskärsverken, outside the town of Skellefteå, is a large smelting company which mainly extracts metals from concentrates of copper, lead and recycled materials (Rönnskärsverken, 2011). At the time of the interviews there were roughly 840 employees in the company, of which about a hundred were women. Kalix Tele 24 is a Call Centre company concerned with receiving and transmitting telephone calls for customer companies (Kalix Tele24, 2011). They had about 150 workers, of which 50 were men. Most of the telephone operators in this company were women. In the Luleå municipality janitors, machinists and cleaners in the Technical Division were focused on (Luleå, 2011). The Division consists of approximately 445 people, roughly an equal number of women and men although occupying very gender stereotypical roles. In the Piteå municipality, elderly and disabled care in the Social Service Division was studied (Piteå, 2011). This Division had about 1,400 workers of which around ten per cent (150) were men.

Three different levels of employees were interviewed in each organisation. The first round of interviews was with human resource managers and people with similar functions. The rationale for this was our understanding that these role players were well aware of the organisation's strategic planning for the development and recruitment of knowledge and skills. Team leaders and foremen were interviewed next regarding the practice of developing, articulating and putting knowledge and skills to work in the organisation. Finally, union 
representatives in each organisation were interviewed in order to ascertain their views, and indirectly the view of the workers they represent, concerning how the organisation approaches employees' skills. The reason for not interviewing workers themselves was because we wanted our primary focus to be a strategic view of each organisation's assessment activities.

The interviews were semi-structured in the sense that certain thematic questions were prepared in advance but the approach was characterized by an openness and willingness to follow unexpected and seemingly interesting leads. The interviews were conducted at each respective workplace and lasted between 45 minutes and one and a half hours. In total 21 interviews were undertaken.

Our own understandings of RPL played a pivotal role in research design. This means that concepts such as evaluation, assessment, documentation and recognition were used as starting points for developing an understanding of how knowledge and skills were recognised within the organisations. However, this was merely a starting point and in the data analysis phase a more inductive approach was used, where hypotheses were developed through close reading of the transcribed and printed interviews (Strauss and Corbin, 1998; Charmaz, 2006).

\section{Research findings}

In the organisations that were studied it seemed that knowledge and skills were conceptualised and assessed in many different ways although seldom through planned or organised activities. Rather, this could be seen as part of established and embedded organisational routines and workplace culture practices. It became clear that employees' knowledge and skills were assessed and evaluated first and foremost in order to be used in the production/activities of the organisation. It was not only "home-grown" skills, such as the skills developed through in-house training courses that were of interest. Knowledge and skills that were entering the organisations, for example, when new personnel were recruited were also of high interest as were those that were on their way out of the organisation, for example when people leave or retire. This makes it possible for us to talk about a 'system' of knowledge and skill assessment within these organisations, which we refer to in the rest of the article as Workplace RPL ('arbetsplatsvalidering' in Swedish). This does not imply the refined meaning of the word system as a well-defined and clearly articulated organisation of assessment activities but rather an accumulation of assessment activities which together form a type of system, certain aspects of which are foregrounded in any one context. In this paper four different aspects of Workplace RPL will be presented and related to the four organisations in the study.

\section{Knowledge and skills - on their way into the organisation}

A part of societal agreements is that formal education degrees stand as proof and a guarantee of a more or less well-known content set of knowledge and skills (Beetham, 1991; Beck, 1998). From an RPL perspective, formal education can be seen as assessed knowledge and skills, often enjoying a high degree of legitimacy. This was generally confirmed in interview data although with certain reservations. Academically qualified workers about to be employed, for example in the Social Service Division in the Piteå municipality, seemed to be more or less stereotypically perceived as 'just' academics. They were viewed as well educated with attendant generalized characteristics such as high levels of social and verbal ability, a motivation for developing their talents and a drive of their own. However, some form of assessment was still required in order to ascertain if and in what way these generalized 
characteristics were expressed by a prospective employee and the degree of fit with the workplace and potential colleagues. Although formal qualifications reflect already assessed and acknowledged knowledge and skills, this does not preclude further assessment of character traits, drive and ambitions on entry into an organisation.

Experience can also be added to the requirements. When machinists or janitors in the Technical Division of the municipality of Luleå are employed, formal education, generally at upper secondary level, is needed. However, this is hardly ever enough on its own. New employees are seldom below the age of 40 , which means that practically speaking they have about 20 years experience in their trade over and above their initial education. The foremen who were interviewed argued that the working situation demands socially as well as professionally skilled workers, people who are friendly and confident, who know how to handle people and who are tough enough to deal with difficult and demanding customers. From their perspective, these requirements are very difficult for young and recently educated plumbers or electricians to meet, and far more suitable for experienced workers with many years in the field. This type of skill assessment could be said to have both general and specific aspects to it. Vocational skills could be assessed in general terms based on the formal qualification. Work experience means that specific, additional skills are acquired (and indeed required). These needed to be assessed and evaluated as part of the recruitment process. This can be compared with the academically educated workers in the Social Service Division in Piteå where academic education was not really enough.

At Rönnskärsverken, recruitment is largely based on mandatory levels of formal education depending on the function and level of the job but with upper secondary schooling as a minimum (this is the case in most Swedish workplaces) (Åberg, 2002; Olofsson, 2005). In spite of this, one union representative reported that temporary workers sometimes acquired permanent jobs on the basis of fellow employees' recommendations. This does not imply that formal education carried no weight but does suggest that a complementary type of assessment based on the everyday observations of co-workers can play an important perhaps crucial role. These short examples of different types of knowledge and skill assessment in everyday work situations show that even formal education is evaluated in different ways before it is utilised.

\section{Knowledge and skills - developed in the organisation}

Many of the machinists in the Technical Division of the municipality of Lulea work in solitude in engine rooms. Their work also involved tasks that were not necessarily part of their formal education. For instance, a trained plumber would have to turn a hand to "layman" jobs in other occupations due to work demands and pressures. Moreover, according to a union representative, despite the machinists being continually enrolled on courses in new techniques and so on, they often invented work-related solutions by themselves. This type of informal learning in the workplace was spoken of in a tone that made it clear that it was something to be proud of and developed. The new knowledge was often brought to the staff room at break times where it was discussed and analysed. This functioned as an informal type of a 'knowledge and skill assessment' where new experience and knowledge was approved (or not) by those workers who were specialists in the area concerned. This type of assessment of workplace learning was informal but nevertheless a part of the culture of the team. In the next example, assessment was a planned and formal part of an organisational strategy.

Operators involved in the initial stages of an education and training programme at Kalix Tele24 were subjected to planned and organised supervision. This involved a mentor who 
showed the newcomer how to manage the computer programme where all the calls were displayed as well as training her/him in how to give the right customer reception. The computer screen showed different kind of pictures of happy or serious faces depending on what type of company they were representing and receiving calls on behalf of. A happy face could mean that an operator was representing for example a garage or vehicle repair company where customer would not expect a particularly formal or serious reception. Conversely, when answering on behalf a law firm a more serious face was displayed on the monitor implying that a different approach was needed. As the programme progressed and the operators were nearly fully trained, the mentor simply sat alongside and commented when needed.

Every step of the programme was documented as part of the continuous training required in order to become a company-certified operator. The company had different competence levels for the operators depending on different customer types, content, character of phone calls, and so on. This meant that not all operators had the certification to receive phone calls on behalf of all customers. Even though operators' knowledge and skills were formally assessed and officially acknowledged via an internal company-specific certificate, this carried value beyond the immediate context. According to one of the production leaders, Kalix Tele24 enjoyed high status among other call centres in Sweden. This leader cited how her sister, a former company employee, had had no problems in gaining work contracts at other centres when mentioning Kalix Tele24. This is as an example of how connection to a certain name or trademark can be equal to an assessment and acknowledgement of one's knowledge and skills, at least to a certain degree.

\section{Knowledge and skills - on their way out of the organisation}

When people were heading towards the end of their employment there was evidence of strategies to "milk" their knowledge and skills. This was particularly the case at Rönnskärsverken, where specially designed leaving conversations were used whenever someone's employment was terminated whatever the cause. The aim of these conversations was for the company to acquire important information about their respective work situations. The Maintenance Division at Rönnskärsverken did this using a custom-designed computer programme; covering for example 'tips and tricks' regarding certain engines and machines were working. This was reporting as creating some opposition amongst the workers who exclaimed: "Are you going to empty me?!" It seemed as if the workers experienced the knowledge and information that the company wanted as their own. Although this was not discussed at length by employees or union representatives in the course of this study, it can perhaps be seen as a strategy to retain a certain balance between knowledge and skills officially acknowledged and used in some way by both the company and the employees and elements of tacit knowledge and skill that the employees saw as a factor in their status, power, bargaining or negotiating authority. This may also indicate that the workers were in some sense aware that the company sought to assess and evaluate their knowledge and skills for production and profit reasons including knowledge not fully documented or acknowledged previously. As in the more highly developed study by Lysgaard (1961) one strategy of resistance for employees is to keep some knowledge and skills to themselves.

One of the operators at Kalix Tele24 was very proud of the knowledge and skills she had developed in the workplace. She and others had the idea that this could be quite useful when finding or changing job. However, it seemed as if this confidence was based on informal verbal feedback they had received from professionals in the workplace and was not supported 
by documentation or certification. The interviewees could not say how they would prove their competence to a potential future employer. Some of them realised that the skills they possessed which were so self-evident in the current context probably only existed in the heads of the present foremen or team leaders and could therefore be difficult to prove in relation to a new work situation.

Both of the above examples point to the fact that organisations try to find ways to assess the character and value of the knowledge and skills that are about to leave the workplace but that this is not always for the benefit of the departing worker, as it perhaps is in ordinary RPL processes with documentation and acknowledgement of one's skill.

\section{Knowledge and skills - not always made visible}

Kalix Tele24 made extensive use of the competence of the operators in its marketing activities. The skill that was most celebrated was operator flexibility in answering calls from a wide variety of customers. This demanded a very well-developed capacity to - in a split second - change voice, approach and words depending on who was calling. It could be described as a qualitative aspect of operator skill as operators, which as mentioned was used to market the company. In contrast, when the company wanted to stress operator competence in the everyday life of the workplace, more quantitative factors were emphasised. The company had a bonus system whereby numbers of received calls gave the operators an opportunity to increase their salary. This system was sometimes enhanced by time-limited competitions where prizes were awarded to those who exceeded a specific number of phone calls within a set period of time. In this way, the focus of operator skill moved from qualitative to quantitative dimensions. Moreover, statistics showed that the operators who scored highly numerically also scored low on faults or complaints; this was taken as a good reason to continue with the system. However the operators were of the view that the salary system downplayed the qualitative aspects of their competence as Call Centre operators. This could be seen as an organisation's way of making knowledge and skills "invisible". It is not that these aspects of competence were completely unacknowledged, but when it came to the reward system, judgements were made only in terms of quantity.

Another example of companies choosing to focus only on particular aspects of competence was when the Rönnskärsverken plant introduced a new workplace planning system at the team level. This was called Team Reception and involved much greater participation on the part of employees in planning the activities of each team, for example, joint planning of schedules, purchases and investments, organising staffing rotas, and so on. Prior to this organisational change, these activities had mainly been the responsibility of the foremen or team leader. Now everybody was not only involved but also supervised by the team leader and in many ways directed by the management. This shift of responsibility within teams can also be seen as a way to render knowledge and skills invisible: what has originally been the domain of a couple of people has now become diffused, collective and less specialised, perhaps even trivialised in the process. The suggestion here is that the development of more effective and productive procedures and models may mean that some aspects of workers' knowledge and skill are not always valued equally, and indeed may be hidden from view.

\section{Conclusion and discussion}

The aim of this paper has been to exemplify and discuss employers' logics in assessing knowledge and skills. We have analysed how employees' knowledge and skills are assessed 
and acknowledged (by management and by the workers) at different stages of the work cycle i.e. on recruitment, within the workplace, and on leaving the organisation. This has been undertaken in order to compare these logics with "traditional" RPL processes, and we have shown that these logics are quite different. Generally speaking, traditional RPL has the explicit purpose of producing documentation of individuals' knowledge and skills, which can be used as proof of competence when presented to different stakeholders (Challis, 1993; VEETAC, 1993). The strength of traditional RPL is obvious: contextual transferability via documents that communicate formalised knowledge/skills for all to see. This cannot generally be said of the exemplified Workplace RPL since its purpose is utilisation rather than transferability. This does not necessarily mean that learning is acknowledged through documentation or officially approved. It could even be said that under certain conditions it is more important for an employer not to make knowledge and skills visible through explicit assessment methods since this sheds light on aspects of competence in a light that may not be in employers' interests.

Earlier in the paper, workplace RPL was referred to as a "system" for assessing the knowledge and skills of companies and municipalities. However, it is a "system" that seems to be both articulated and tacit, mirroring the skills that are being assessed. Such a "system" can be a trap for the employer and the worker. Knowledge and skills that are developed in the workplace often receive credit and attention from both management and colleagues through their utilisation in the immediate work situation. The problem is that this type of assessment has a short range that often does not reach outside the context in which it was originally developed.

It can be argued that since its introduction into European Union debates in the 1990s, traditional RPL has been regarded as a powerful tool for articulating informal (and nonformal) learning in the workplace. What this article seeks to emphasise is both the need to and the importance of understanding the obstacles and opportunities that lie within these two systems of assessment i.e. within 'traditional' RPL and in what we have called Workplace RPL. The issue that therefore needs to be discussed further is the implications for employers and employees if Workplace RPL were to adopt a more traditional style of RPL with the objective of producing, in some way or the other, officially acknowledged documentation and certification.

For the employer it is of course obvious that the general use of traditional RPL in the workplace would involve higher costs with uncertain outcomes and a risk of losing important competence. On the other hand, the absence of documentation regarding the knowledge and skills of employees brings much uncertainty to the organisation, since important competence that may be dormant in the organisation will not be valued and acknowledged and therefore cannot be utilised. Another important aspect is the influence that knowledge and skills can have on the legitimacy of the company (Beetham, 1991; Hill, 2007; Røvik, 2008). The ability to market the existence of appropriate and high standard competence has become an important issue for most organisations, not least for municipalities in relation to citizen and user demand (Røvik, 2008). In this regard, RPL can be used in order to articulate the knowledge and skills that are available in the organisation.

As mentioned, more traditional RPL can strengthen individual workers' positions in the labour market. This can be of particular importance where there is a need for flexibility and for evidence of transfer competence between different projects. In such cases RPL is a useful method in making visible the requisite knowledge and skills. Our empirical data exposed 
something of this dilemma when several employees who were very proud of their achieved competence were rather unsure whether this would be transferable and translatable into other contexts. Another important aspect of RPL that is seldom discussed in workplace contexts is the empowering and motivating nature of the assessment process, something which could become a win-win situation for both the employer and the employee (Challis, 1993;

Andersson and Fejes, 2010). Recognising the skills of employees can provide weighty confirmation of their worth and also ignite motivation and innovation. The uncertainty attached to undocumented competence could therefore be exchanged for the satisfaction of certification.

In conclusion, there are several reasons for increasing the use of traditional RPL in workplace contexts. But for this to happen it is important to understand the pre-existing "system" of assessment and recognition in workplaces and the logic for its existence. Without this understanding, it will be difficult to unify the two systems. Finally, for society as a whole, the value of RPL in workplaces centres on enhancing the readiness for change in highly flexible contexts and minimising the risk of unemployment. 


\section{References}

Åberg, R. (2002), "Överutbildning: ett arbetsmarknadspolitiskt problem?”, in Abrahamsson, K., Abrahamsson, L., Björkman, T., Ellström, P-E., Johansson, J. (Eds), Utbildning, kompetens och arbete, Studentlitteratur, Lund, pp. 41-61.

Andersson, P. and Harris, J. (eds) (2006), Re-theorising the recognition of prior learning, NIACE, Leicester.

Andersson, P. and Fejes, A. (2010), Kunskapers värde: validering i teori och praktik, 2nd edition, Studentlitteratur, Lund.

Andersson, P., Fejes, A. and Ahn, S-e. (2004), "Recognition of Prior Vocational Learning in Sweden", Studies in the Education of Adults, Vol. 36 No. 1, pp. 57-71.

Beck, U. (1998), Risk Society: Towards a New Modernity, SAGE Publications, London.

Beetham, D. (1991), The Legitimation of Power, Issues in Political Theory, MacMillan Press, London.

Berglund, L. (2010), På spaning efter arbetsplatsvalidering. En undersökning av fyra organisationers synliggörande av kompetens (Searching for Work Place RPL: A study of the ways competence is visualised in four organisations), Dissertation, Luleå tekniska universitet, Luleå.

Billet, S., Fenwick, T. and Somerville, M. (Eds) (2006), Work, Subjectivity and Learning: Understanding Learning through Working Life, Springer, Dordrecht.

Billet S. (2006), "Work, Subjectivity and Learning" in Billet, S., Fenwick, T. and Somerville, M. (eds), Work, Subjectivity and Learning: Understanding Learning through Working Life, Springer, Dordrecht, pp. 1-20.

Bjørnåvold, J. (2000), Making learning visible: identification, assessment and recognition of non-formal learning, Cedefop - European Centre for the Development of Vocational Training, Tessaloniki.

Boud, D. (2000), "Sustainable Assessment: rethinking assessment for the learning society", Studies in Continuing Education, Vol. 22 No. 2, pp. 151-167.

Challis, M. (1993), Introducing APEL, Routledge, London.

Charmaz, K. (2006), Constructing grounded Theory, SAGE Publications, Los Angeles.

Colardyn, D. (1997), "Validering av kunskap och kompetens för livslångt lärande", in Å. Mäkitalo and L-E. Olsson (eds.), SOU 1997:158. Vuxenpedagogik i teori och praktikKunskapslyftet i fokus. Utbildningsdepartementet, Kunskapslyftskommittéen, Fritzes, Stockholm, pp. 283-300.

Colardyn, D. and Bjørnåvold, J. (2004), "Validation of Formal, Non-Formal and Informal Learning: Policy and Practices in EU Member States", European Journal of Education, Vol. 39 No. 1, pp. 69-89.

Ellström, P-E. (1992), Kompetens, utbildning och lärande i arbetslivet, Problem, begrepp och teoretiska perspektiv, Publica, Stockholm.

Evans, N. (2003), Making sense of lifelong learning: respecting the needs of all, RoutledgeFalmer, London.

Fejes, A. and Andersson, P. (2009), "Recognising prior learning: Understanding the relation among experience, learning and recognition from a constructivist perspective", Vocations and Learning: Studies in Vocational and Professional Education, Vol. 2 No. 1, pp. 37-55.

Fenwick, T. (2005), "Learning as Grounding and Flying: Knowledge, skill and transformation in changing work contexts", paper presented at From ground to skills to skyqualifications, August 17-19, 2005, Kiruna, Sweden, available at: http://www.larena.se/dokument/kirunapapers/FENWICK-Kiruna\%20paper.pdf (accessed 30 August 2011). 
Fenwick, T. (2006), "Reconfiguring RPL and its assumptions: a complexified view", in Andersson, P. and Harris, J. (eds), Re-theorising the recognition of prior learning, NIACE, Leicester, pp. 283-300.

Hill, M. (2007), The Public Policy Process, Pearson Education Limited, Harlow, England.

Kalix Tele24 (2011), Home page of the company Kalix Tele24, available at: http://www.kalixtele24.se (accessed 1 September 2011).

Kok, W. (2004), Facing the challenge. The Lisbon strategy for growth and employment. Report from the High Level Group chaired by Wim Kok, Nov 2004, Office for Official Publications of the European Communities, Luxembourg.

Lave, J. and Wenger, E. (1991), Situated learning: legitimate peripheral participation, Cambridge University Press, Cambridge.

Luleå (2011), Home page of the municipality of Luleå, available at: http://www.lulea.se (accessed 1 September 2011).

Lundgren, A. (2005), På längre sikt. "Kompetenshimmel eller deltidshelvete?" En utvärdering av samarbetsprojektet Hållbar kompetensutvecklingsmodell under åren 20032004, Luleå Tekniska Universitet, Luleå.

Lysgaard, S. (1961), Arbeiderkollektivet: en studie i de underordnedes sosiologi, Universitetsförlaget, Oslo.

Ministry of Education (2003), Validering m.m. - fortsatt utveckling av vuxnas lärande, Ds 2003:23, Regeringskansliet, Stockholm.

Nordhaug, O. (1993), Human capital in organizations, Scandinavian University Press, Oslo.

Olofsson, J. (2005), Svensk yrkesutbildning. Vägval i internationell belysning, SNS Förlag, Stockholm.

Piteå (2011), Home page of the municipality of Piteå, available at: http://www.pitea.se (accessed 1 September 2011).

Romaniuk, K. and Snart, F. (2000), "Enhancing employability: the Role of Prior learning Assessment and Portfolios", Career development international, Vol. 5 No. 6, pp. 318-322.

Rubenson, K. (1996), "Livslångt lärande: mellan utopi och ekonomi”, in Ellström, P-E., Gustavsson, B., Larsson, S. (eds) (1996), Livslångt lärande, Studentlitteratur, Lund, pp. 29-47.

Rönnskärsverken (2011), Home page of the company of Rönnskärsverken, available at: http://www.boliden.se (accessed 1 September 2011).

Røvik, K. A. (2008), Managementsamhället: trender och idéer på 2000-talet, Liber, Malmö.

Sandberg, F. (2010), "Recognising health care assistants' prior learning through a caring ideology", Vocations and Learning: Studies in Vocational and Professional Education, Vol. 3 No. 2, pp. 99-115.

Strauss, A., Corbin, J. (1998), Basics of Qualitative Research. Techniques and Procedures for Developing Grounded Theory, SAGE Publications, Thousand Oaks.

Tursell, A. (2005), Validering i centrum: $i$ Göteborg och Malmö, Valideringscentrum i Göteborgsregionen, Valideringscentrum i Malmö stad, Göteborg, Malmö.

VEETAC (1993), Arrangements for the Recognition of Prior Learning in Australia, Vocational Education, employment and training advisory committee, Canberra, Commonwealth of Australia.

Weber, M. (1978), Economy and society: An Outline of Interpretive Sociology, University of California Press, Berkeley. 